\title{
Morphological Study of the Cervical Salivary Glands in the Nine-Banded Armadillo
}

\author{
Estudio Morfológico de las Glándulas Salivales Cervicales en el Armadillo de Nueve-Bandas
}

\author{
Bruno Cesar Schimming
}

SCHIMMING, B. C. Morphological study of the cervical salivary glands in the nine-banded armadillo. Int. J. Morphol., 27(3):737$742,2009$.

SUMMARY: The cervical salivary glands of the armadillo Dasypus novemcinctus was examined by light microscopy. These glands are situated on either side of the neck, divide in lobes and show a presence of a salivary bladder, associated with the main ducts of the gland. This gland is histologically a typical mixed glands, containing both mucous and serous elements, with mucous acini as the predominant secretory unit. The bladder itself is composed of a wall made up of pseudostratified epithelium, skeletal muscle and connective tissue. In general, the morphology of the cervical salivary glands appears similar to that described in other species of the mammals.

KEY WORDS: Armadillo; Salivary glands; Cervical salivary glands; Morphology.

\section{INTRODUCTION}

The nine-banded armadillo (Dasypus novemcinctus, L.) has been become the subject of great interest, since that species is the first unaltered animal model to develop human leprosy following inoculation with Mycobacterium leprae. That the originator bacillus is genetically identical to the human bacillus (Opromolla et al., 1980; Folse \& Smith, 1983; Meier et al., 1983). The armadillos show adaptive and primitive characteristics in both anatomical and physiological aspects (Galíndez et al., 2000).

The armadillo diet consists of insects, worms, small vertebrates, some vegetable materials and carrion (Estecondo et al., 2005).

The salivary glands of severals mammals has been the subject of numerous studies (Fava de Moraes, 1965; Wilborn \& Shackleford, 1969; Watanabe et al., 1996; Tandler et al., 1997; 1998; Cangussu et al., 2002; Lentle et al., 2002; Ogawa, 2003; D'Avola et al., 2006).

In the Dasypodidae family, the histology and ultrastructure of the salivary glands also has been studied (Shackleford, 1963; Fava de Moraes; Ruby, 1978; AbreuRays et al., 1993; Codón et al., 2003; Estecondo et al.).
The armadillo is an animal with different environments and eating habitats. Thus, the armadillo's salivary glands study is interesting. In this paper, the anatomical and histological characteristics of the cervical salivary glands of nine-banded armadillo was studied and compared to the morphology of other salivary glands of the armadillo and of other mammals.

\section{MATERIAL AND METHOD}

Five adult nine-banded armadillos Dasypus novemcinctus of both sexes were used. Two animals were fastened in formol solution at $10 \%$. Their cervical region has been dissected. After dissection, the cervical salivary glands were identified, and described.

The glands of three armadillos were used in histological studies. They were fixed in Bouin's fluid, dehydrated in graded ethanol and embedded in paraffin. Sections $7 \mu \mathrm{m}$ thick were stained with haematoxylin and eosin and Masson's trichrome. They were examined and photographed with a Olympus BH-2 microscope. The 
nomenclature used in this study was according to the pattern established by Schaller (1999) (International Committee of Veterinary Gross Anatomical Nomenclature).

\section{RESULTS}

Two cervical salivary glands are of big dimensions are distinguished in each animal (Fig.1). They are situated on either side of the neck just below the mandible; ventrally from the sternocephalicus muscles (the superficial sternomandibularis and the deep sternostoideus muscles), and medially from pectoralis superficiales muscles.

These glands show a presence of a salivary bladder associated with the main ducts of the gland (Fig.2).

The gland is surrounded by a fibrous capsule, which consists of dense connective tissue. The capsule connective tissue is continuous with the interstitial connective tissue that consists of a loose connective tissue and divide the gland in such a manner that distinct lobules are evident histologically (Figs. 3 and 4). The lobules are composed of secretory unit and ducts. Adjacent lobules are separated by a thin layer of connective tissue.

The armadillo cervical salivary glands are compound branched tubular organs that connect in the following order to convery saliva toward the oral cavity: secretory units, intercalated ducts, striated (intralobular) ducts, excretory (interlobular) ducts, intralobar ducts, lobar ducts, salivary bladder and excretory ducts (Figs. 1-9).

Histological studies reveals that cervical salivary glands in the nine-banded armadillo are typical mixed glands containing both mucous and serous elements, with mucous acini as the predominant secretory unit (Figs. 3, 4 and 6). The mucous secretory cells arranged in acini around a central lumen that communicates with the ductal system. Nuclei of the mucous cells are oval, flattened toward the base of the cell and stain darkly with haematoxylin. The acinar cytoplasm stains pale blue in Masson preparations (Figs. 3 and 6).
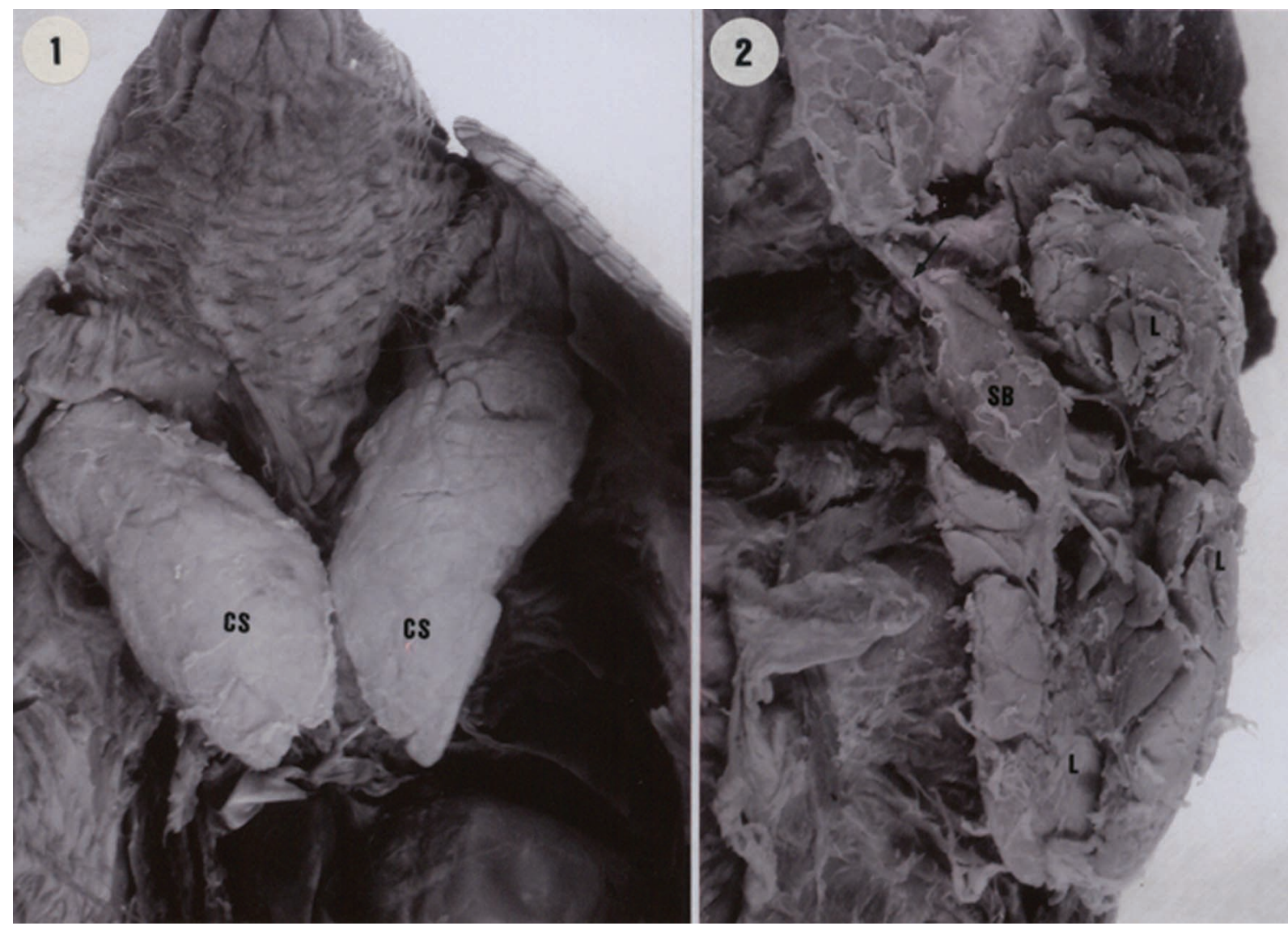

Figs. 1 and 2: Cervical salivary glands (CS) in the nine-banded armadillo. Note the salivary bladder (SB), lobes (L) and excretory duct (arrow). 
The cervical salivary glands has a little number of acini containing serous cells. The serous cells in such acini are pyramidal and darkly staining. Nuclei are rounded and basally located (Fig. 6).

It is possible, observed myoepithelial cells, that are juxtaposed intimately to the secretory epithelial cells of the alveoli.
The salivary bladder is composed of three distinct layers: an epithelium, a submucosa and a coat of skeletal muscle. The bladder is lined by a pseudostratified columnar epithelium. This epithelium is composed by a principal and basal cells. The submucosa is composed primaraly of collagen fibers. It also contains numerous blood vessels, and nerve bundles. The nerves are usually confined to the area between the connective tissue layer and the skeletal muscle (Fig. 9).
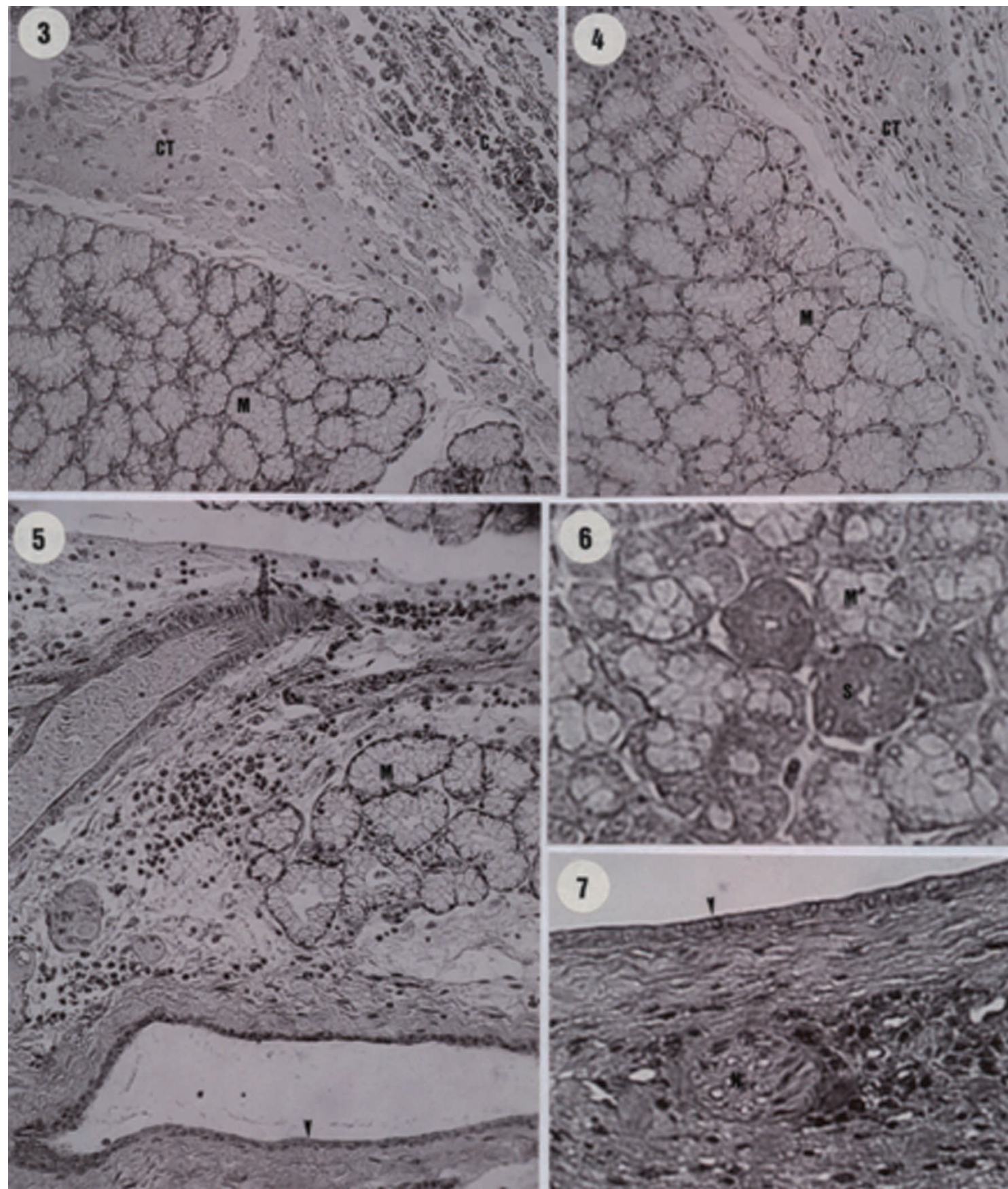

Figs. 3-7: Light micrographs of the cervical salivary glands. In the figures, can observed mucous acini (M), serous acini (S), septa of connective tissue (CT), connective tissue of the capsula (C) and nerve (N). Arrowheads indicates epithelium of the salivary bladder. Figs. 3 and 4, HE. x100. Fig. 5, Masson. x100. Fig. 6, HE. x100. Fig. 7, Masson. x200. 


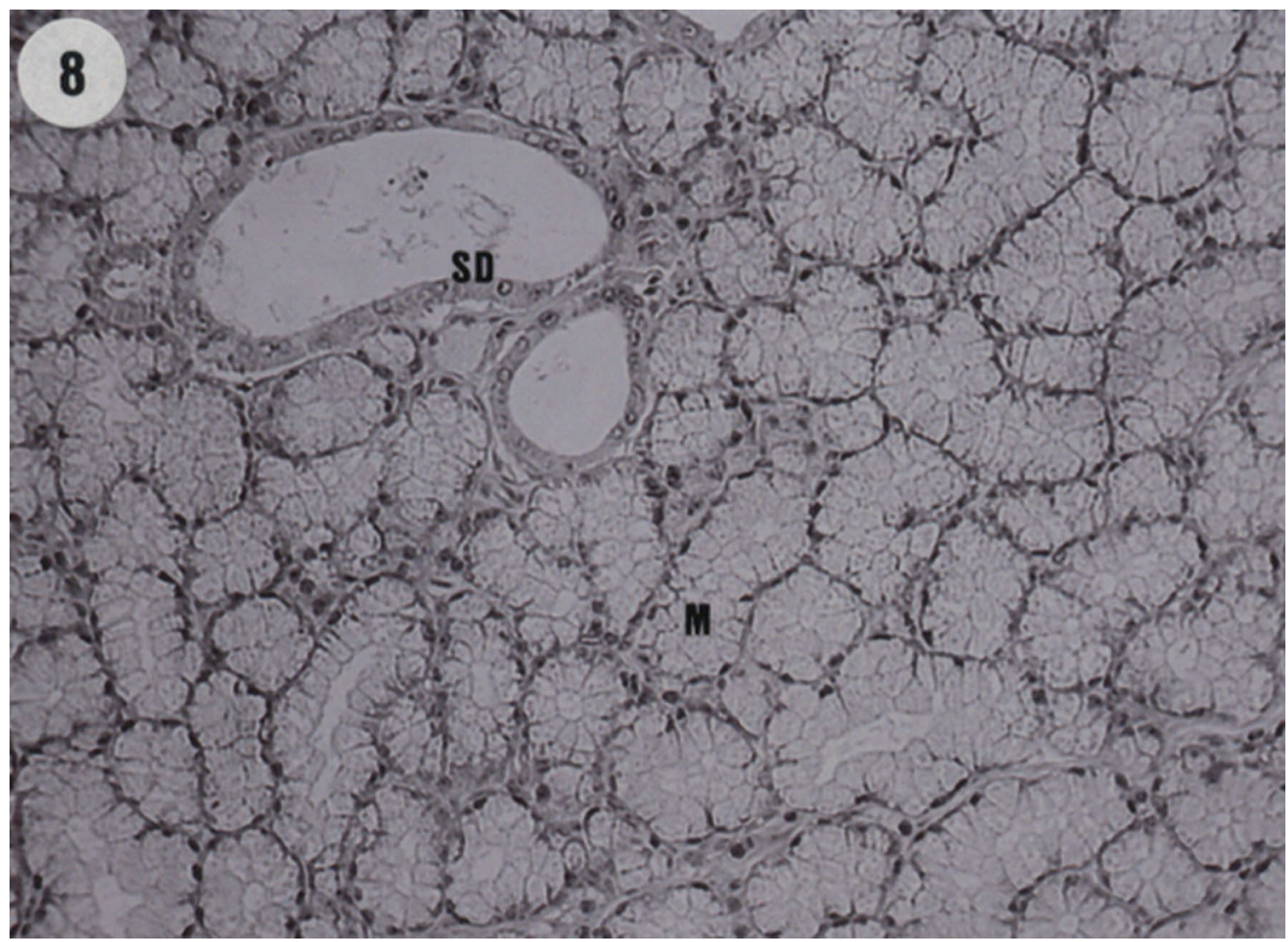

Fig. 8: A striated duct (SD) and mucous acini (M) in the gland. HE, x100.

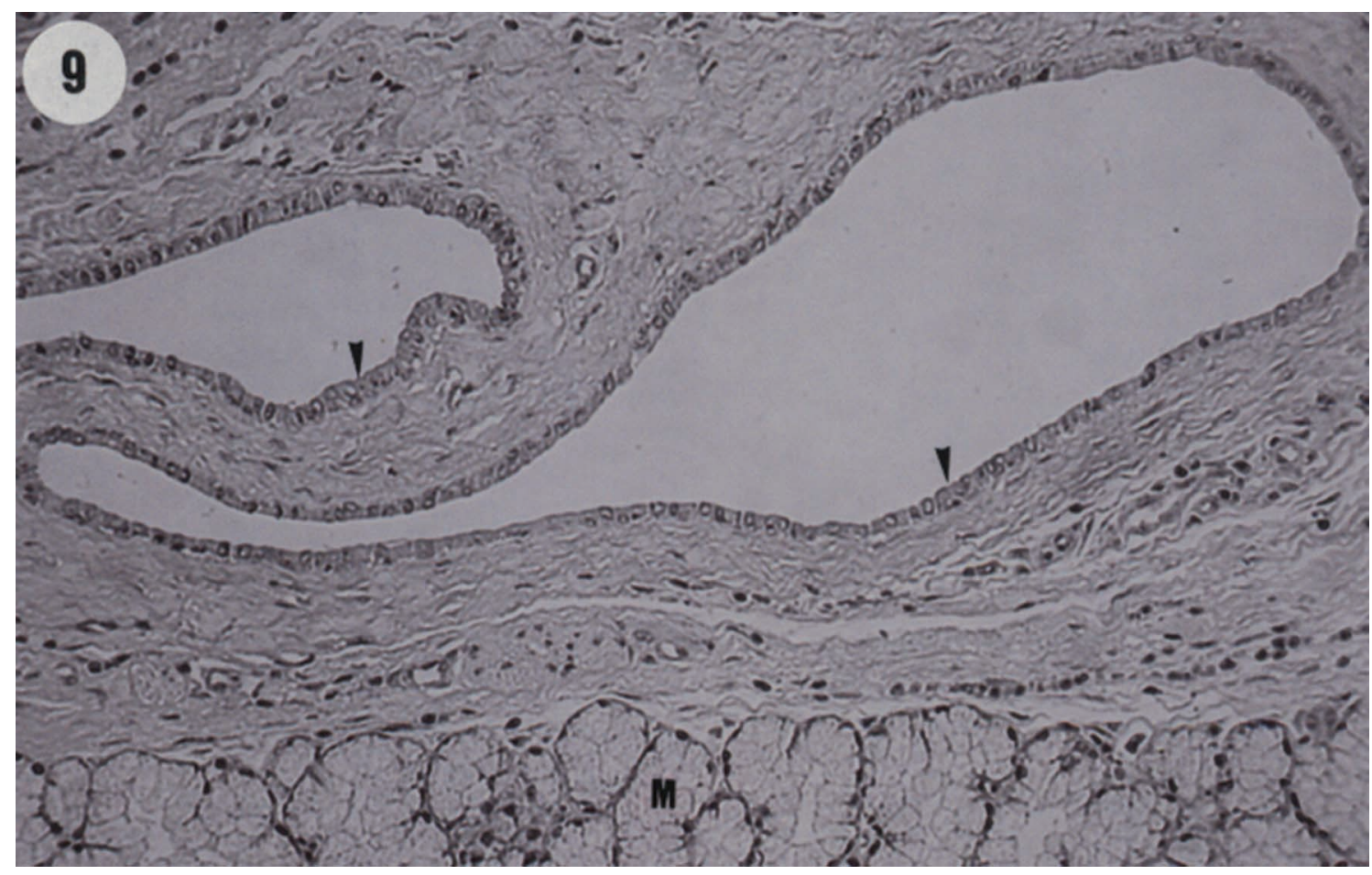

Fig. 9: Epithelium of the salivary bladder (arrowheads) and mucous acini (M) are showed. HE, x100. 
A system of ducts linked the secretory elements of the cervical salivary glands to the oral cavity. This system are divided into three segments, intercalated, secretory (striated) and excretory. The intercalated and secretory ducts are located in connective tissue septa within glandular lobules (intralobular), whereas the excretory ducts are located in connective tissue between lobules (interlobular). The intercalated ducts are small tubular lined by a low cuboidal epithelial. They connect alveoli to striated ducts. Several intercalated ducts join to form the secretory duct. The striated ducts are lined by a cuboidal to columnar epithelium. Secretory ducts drain into the excretory ducts. Lobular ducts are lined by stratified columnar epithelium or cuboidal. The larger ducts (intralobar ducts, lobar ducts and excretory ducts) may be lined by pseudostratified columnar epithelium (Figs. 2-7).

\section{DISCUSSION}

The morphology showing by the cervical salivary glands of Dasypus novemcinctus is similar to those of salivary glands of other mammals. These glands are a typical mixed glands containing both mucous and serous elements. The parotid gland is a typical serous gland in the Dasypus novemcinctus (Shackleford; Fava de Moraes), in the Dasypus hybridus (Codón et al.) and in the Zaedyus pichiy (Estecondo et al.). Ruby reported that the armadillo parotid gland demonstrated that the acinar cells are seromucous.

Generally, the submandibular was divided in two lobes, when the posterior lobe was predominantly mucous (Shackleford; Codón et al.; Estecondo et al.).

The sublingual gland have not been observed in
Dasypus novemcinctus (Shackleford) and Dasypus hybridus (Codón et al.). In other mammals, the sublingual gland is a mixed serous and mucous tubuloacinar gland in which mucous acini predominate, similarly to this study, when the mucous acini as the predominant secretory unit of the cervical salivary glands.

The presence of a cervical salivary glands of Dasypodidae was carried out on Dasypus hybridus or mulitas by Cuba Caparo (1978). During autopsy, this author were extracted several organs of mulitas, as the cervical salivary gland. Although, the morphology of this gland, this author has not been described previously.

Armadillo cervical salivary gland acini resemble those of the related by Abreu-Rays et al. in view of the mixed mucous and serous acini in these glands of the armadillos.

A remarkable feature of this study is the presence of a salivary bladder in the Dasypus novemcinctus. The presence of a salivary bladder is a characteristic of armadillos (Codón et al.). It has been observed in Daspypus novemcinctus (Shackleford; Fava de Moraes), and Dasypus hybridus (Cuba Caparo; Codón et al.). Since the salivary bladder is surrounded by skeletal muscle, it has been suggested that the armadillo can voluntarily discharge large amounts of stored saliva into the oral cavity for rapid coating of the tongue during feeding for example, in catching insects (Shackleford).

The epithelium lining of the salivary bladder is a pseudostratified columnar epithelium in this study, corresponding with the describe by Codón et al. for Dasypus hybridus. In general, the morphology of the cervical salivary glands of the armadillo appears similar to that described in other species of armadillos and mammals.

SCHIMMING, B. C. Estudio morfológico de las glándulas salivales cervicales en el armadillo de nueve-bandas. Int. J. Morphol., 27(3):737-742, 2009.

RESUMEN: Las glándulas salivales cervicales del armadillo Dasypus novemcinctus fueron examinadas por microscopía de luz. Estas glándulas se encuentran a ambos lados del cuello, divididas en lóbulos y muestran la presencia de una vejiga salival, asociada con los principales conductos de la glándula. Esta glándula es histológicamente una típica glándula mixta, que contiene tanto elementos mucosos y serosos, con acinos mucosos como la principal unidad secretora. La vejiga en sí se compone de una pared formada por epitelio pseudoestratificado, músculo esquelético y tejido conectivo. En general, la morfología de las glándulas salivales cervicales parece similar a la descrita en otras especies de mamíferos.

PALABRAS CLAVE: Armadillo; Glándulas salivales; Glándulas salivales cervicales; Morfología.

\section{REFERENCES}

Abreu-Rays, M. A.; Schimming, B. C.; Matos, D. \& Vicentini, I. B. F. Contribuição ao estudo morfológico das glândulas salivares cervicais superficiais no tatu
(Dasypus novemcinctus, L. 1758). II. Aspectos microscópicos. In: Anais do XVI Congresso Brasileiro de Anatomia, São Paulo, n.181, 1993. 
Cangussu, S. D.; Vieira, F. G. \& Rossoni, R. B. Sexual dimorphism and seasonal variation in submandibular gland histology of Bolomys lasiurus (Rodentia, Muridae). J. Morphol., 254:320-7, 2002.

Codón, S. M.; Estecondo, S. \& Casanave, E. B. Histological study of the salivary glands in Dasypus hybridus (Mammalia, Dasypodidae). Int. J. Morphol., 21(3):199204, 2003.

Cuba Caparo, A. The armadillo in biomedical research. In: The armadillo as an experimental model in biomedical research. Washington, Pan American Health Organization, 1978. pp. 18-25.

D’Ávola, T. E.; Ogawa, K.; Alves e Silva, M. R. M.; Motoyama, A. A.; Inácio, E.; König Jr., B. \& Watanabae, I. Three-dimensional characteristics of submandibular salivary gland of ageing rats: An HRSEM study. Ann anat., 188 (5):431-8, 2006.

Estecondo, S.; Codón, S. M. \& Casanave, E. B. Histological study of the salivary glands in Zaedyus pichiy (Mammalia, Xenarthra, Dasypodidae). Int. J. Mophol., 23(1):19-24, 2005.

Fava de Moraes, F. Alguns dados morfológicos associados ao estudo histoquímico dos polissacarídeos em glândulas salivares de animais pertencentes às seguintes ordens: Marsupialia, Chiroptera, Primates, Edentata, Lagomorpha, Rodentia, Carnívora e Artiodactyla (Mammalia). Revta. Fac. Odont. Univ. São Paulo, 3(2):233-90, 1965.

Folse, D. S. \& Smith, J. H. Leprosy in wild armadillos (Dasypus novemcinctus) on the Texas Gulf Coast: Anatomic pathology. J. Reticulo-endothel. Soc., 34:34157, 1983.

Galíndez, E. J.; Codón, S. M. \& Casanave, E. B. Spleen of Dasypus hybridus (Mammalia, Dasypodidae): A light and electron microscopic study. Anat. Rec., 258:286-91, 2000.

Lentle, R. G.; Hume, I. D.; Kennedy, M. S.; Stafford, K. J.; Potter, M. A.; Springett, B. P. \& Haslett, S. The histology and morphometrics of the major salivary glands of four species of wallabies (Marsupialia: Macropodiae) from Kawau Island, New Zealand. J. Zool., 257(3):403-10, 2002.

Meier, J. L.; Folse, D. S. \& Smith, J. H. Leprosy in wild armadillos (Dasypus novemcinctus) on the Texas Gulf Coast: Ultrastructure of the liver and spleen. Lab. Invest., 49:281-90, 1983.
Ogawa, Y. Immunocytochemistry of myoepithelial cells in the salivary glands. Prog Histochem. Cytochem., 38(4):343-426, 2003.

Opromolla, D. V.; de Arruda, O. S. \& Fleury, R. N. Manutenção de tatus em cativeiro e resultados da inoculação do M. leprae. Hansenol. Int., 5:28-36, 1980.

Ruby, J. R. Ultrastructure of the parotid gland of the ninebanded armadillo. Anat. Rec., 192:389-406, 1978.

Schaller, O. Nomenclatura anatômica veterinária ilustrada. São Paulo, Manole, 1999.

Shackleford, J. M. The salivary glands and salivary bladder of the nine-banded armadillo. Anat. Rec., 145(4):513$20,1963$.

Tandler, B.; Nagato, T.; Toyhoshima, K. \& Phillips, C. J. Ultrastructure of the parotid gland in the common vampire bat, Desmodus rotundus, with special emphasis on oncocytes. J. Submicrosc. Cytol. Pathol., 29:37-49, 1997.

Tandler, B.; Nagato, T. \& Carleton, J. P. Ultrastructure of the binary parotid glands in the free-tailed bat, Tadarida thersites. II. Acessory parotid gland. Anat. Rec., 251:12235, 1998.

Watanabe, I.; Seguchi, H.; Oxada, T.; Kobayashi, T.; Jin, Q. S. \& Jiang, X. D. Fine structure of the acinar and duct cell component in the parotid and submandibular glands of the rat: a TEM, SEM and HRSEM study. Histol. Histopathol., 11:103-10, 1996.

Wilborn, W. H. \& Shackleford, J. M. The cytology of submandibular glands of the opossum. J. Morph., 128:134, 1969.

\section{Correspondence to:}

Prof. Dr. Bruno Cesar Schimming

Animal Anatomy Laboratory Integraded Faculties of Bauru, FIB,

Rua Rodolfina Dias Domingues quadra 11 - s/n

Jardim Ferraz,

CEP 17056-100

Bauru, São Paulo

BRASIL

E-mail: brunoidish@terra.com.br

Received: 16-12-2008

Accepted: 28-05-2009 